\title{
Study of Paulownia's Biomass Production in Mérida (Badajoz), Southwestern Spain
}

\author{
Berdón Berdón, J. ${ }^{1, *}$, Montero Calvo, A. J. ${ }^{1}$, Royano Barroso, L. ${ }^{2}$, \\ Parralejo Alcobendas, A. I. ${ }^{2}$, González Cortés, J. $^{2}$ \\ ${ }^{1}$ Centro de Investigaciones Científicas y Tecnológicas de Extremadura-Instituto del Corcho la Madera y el Carbón vegetal, Spain \\ ${ }^{2}$ Centro de Investigaciones Científicas y Tecnológicas de Extremadura-Finca la Orden, Spain
}

Copyright $(2017$ by authors, all rights reserved. Authors agree that this article remains permanently open access under the terms of the Creative Commons Attribution License 4.0 International License

\begin{abstract}
Fast-growing forest species have become an alternative to take into account for irrigated land with lower profit margins. The objective of this project is to know the adaptation and biomass yields of the Paulownia crop for biomass and timber production, in the irrigated area of the Guadiana River 'Vegas Bajas' in Extremadura Region, (SPAIN). In 2012, two plots with 4 different Paulownia clones were planted (112, COT2, L1 and X1). One plot has been destined to timber production $(\mathrm{T})$, with a 10 -year rotation, grown at 4 by $4 \mathrm{~m}$ spacing, and the other plot has been destined to biomass production (B), with a 3-year rotation, grown at 3 by $2 \mathrm{~m}$ spacing. In February 2016, the first rotation stand of the biomass (B) plot was harvested. Clone X1 has showed a significantly lower performance in terms of dry matter production and growth, whilst among the other 3 clones, no significant differences were observed. The total production of the biomass plot was $24280.1 \mathrm{~kg}$ dry matter ha-1 . Average annual total biomass yield was 8093.4 $\mathrm{Kg} \mathrm{ms} \mathrm{ha}{ }^{-1}$ for plot (B).
\end{abstract}

Keywords Biomass, Fast-growing Trees, Short-rotation Plantation, Paulownia, Timber, Full Random Blocks

\section{Introduction}

The genus Paulownia, original from the rocky and xeric areas of Southeast Asia, is widely distributed throughout the temperate zones of the world, where it is used as a crop [1]. About 50 countries are developing afforestation programs for wood production with some species of this genus, which are characterized by their high yields and their adaptability to different climates and soils [2].

Paulownia has three requirements for its growth [2]:

- Well drained soils, which limits its implantation in clay soils.
- $\quad$ Minimum temperatures below $-20^{\circ} \mathrm{C}$

- Minimum annual rainfall or irrigation of $500 \mathrm{~mm}$. Most of water must be available during warm season. Stations are reported where $65 \%$ of annual rainfall coincides with the growth period of these species.

Its engineering properties, its resistance to pathogens, dimensional stability and a high flash point ensure the quality of the wood for lumber production $[3,4]$.

Its wood is light, soft, straight fiber, slightly knotty and with a glossy luster. Active drying, even at high temperature, does not induce major defects. It has little tendency to warp [5]. Its current uses as saw wood include joinery, carpentry, construction, aviation, packaging, etc.

Paulownia clones are developed in 6-10 years rotations for saw log. In seasons with optimal cultivation conditions, Paulownia trees can reach 10 meters high, with a clean stem of $5 \mathrm{~m}$ and a diameter of 22 centimeters in 4 years. In these sites it is common to have trees of 45 to $50 \mathrm{~cm}$ of diameter at breast height in 10 years, with biomass yields of $12 \mathrm{~m}^{3}$ hectare $^{-1}$ year ${ }^{-1}$. In the United States [6, 7] and other countries, Paulownia is considered as a first class wood, reaching prices even higher than walnut [8]. In Spain the genus Paulownia has been cultivated for the last 10 years, in order to produce timber and biomass. There are studies in which total biomass yields up to $6079 \mathrm{~kg}$ dry matter (d.m.) ha ${ }^{-1}$ year $^{-1}$ and with a crown biomass of 4080 Kg d.m. ha ${ }^{-1}$ [9] up to $12 \mathrm{~m}^{3} \mathrm{ha}^{-1}$ year $^{-1}$ [10].

The aim of this study was to evaluate 4 selected Paulownia clones in short rotation for saw log and biomass production to compare the biomass yields of these clones in the Guadiana River low basin, in Extremadura Region (Southwestern SPAIN).

\section{Materials and Methods}

The study began in 2012 with the planting of two plots, 
one for biomass production $\mathrm{B}$ and the other one for timber production $\mathrm{T}$. The study is based on the clones showed in Table 1:

Table 1. Used clones and species that form them

\begin{tabular}{|c|c|}
\hline Clon & Specie/s \\
\hline COT 2 & Paulownia elongata $x$ fortunei \\
\hline L1 & Paulownia elongata $x$ fortunei \\
\hline X1 & Paulownia fortunei \\
\hline 112 & Paulownia elongata $x$ fortunei \\
\hline
\end{tabular}

In both plots, all the trees were collected at the end of
2012. A biomass production cycle of 3 years was selected, being in February 2016 the first cut of the plot for biomass production (B). In the plot destined to saw log, a cycle of 10 years was provided.

Differences between the four studied clones, in both plots, have been evaluated in a randomized complete block plantation, as shown in Figure 1:

- $\quad$ Plot for Biomass production (B): 8 blocks with 32 trees each ( 8 trees per clone).

- $\quad$ Plot for timber production (T): 13 blocks with 12 trees each (3 trees per clone).

\section{BIOMASS PLOT}

76 border trees

264 trees

66 trees by clon

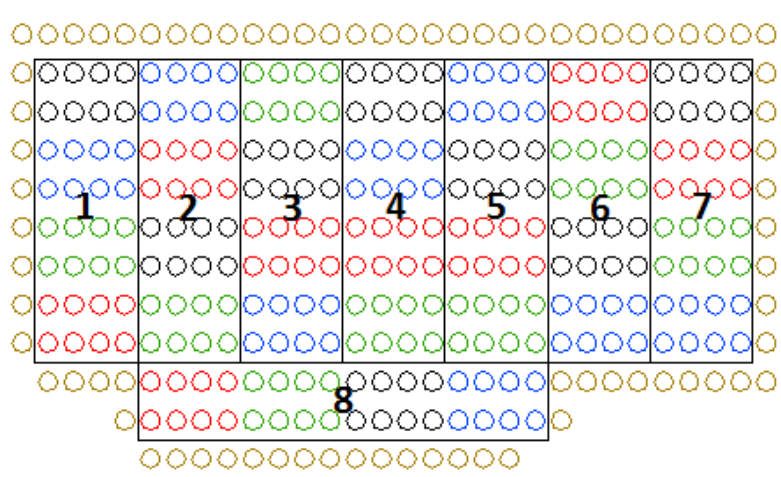

N

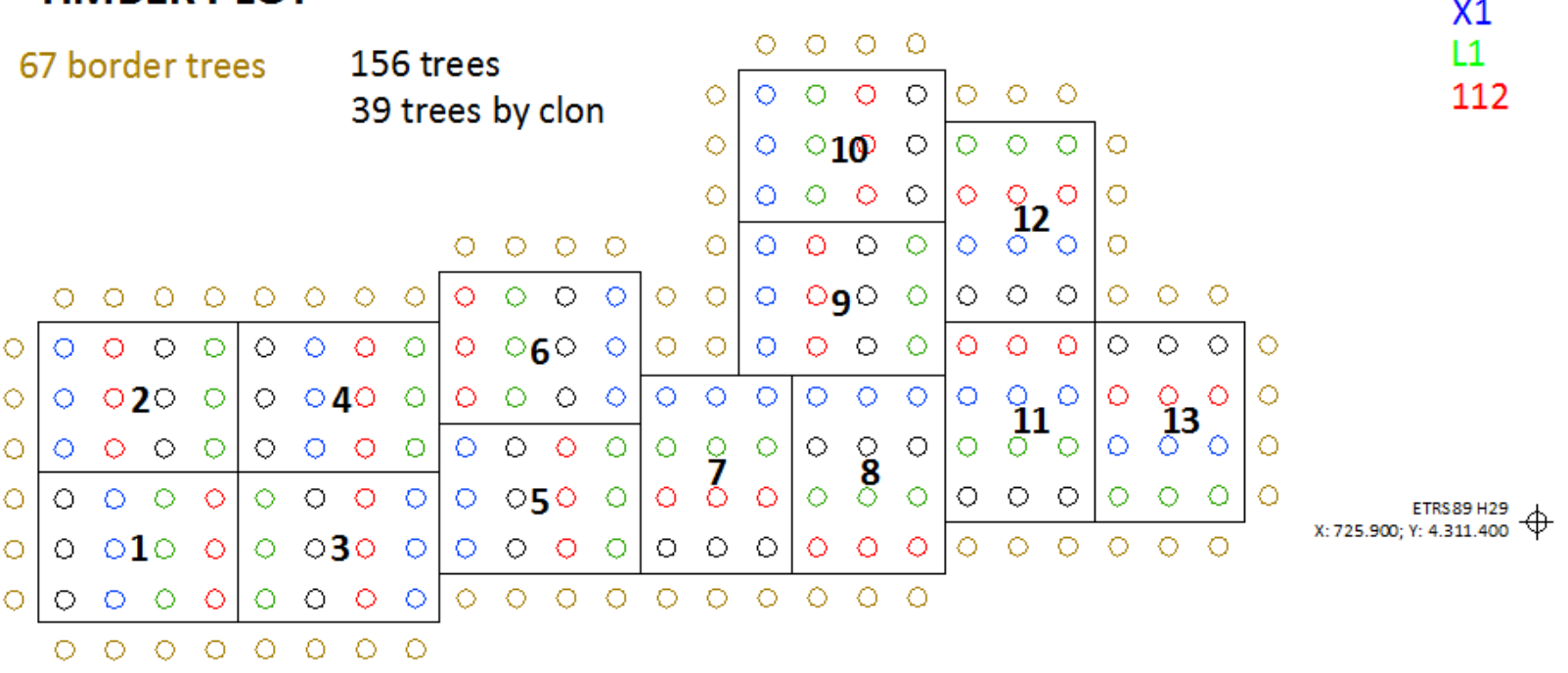

Figure 1. Distribution of the different clones in both plots, above biomass and down timber 


\subsection{Stablishment}

Both plantations are established in Mérida (Badajoz), in the fields of the Cork, Wood and Charcoal Institute (ICMC) of the Technological and Scientific Researches Centre (CICYTEX) of the Extremadura Region (Southwestern SPAIN, ETRS89 H29 X:725.900; Y:4.311.400). The plots have rocky soils of alluvial origin with low organic matter, $\mathrm{pH} 7,5-8,5$. The average annual temperature is $16,9^{\circ} \mathrm{C}$ and the average annual rainfall is $486 \mathrm{~mm}$.

The north side of the field was selected for the production of biomass and the south side for timber production. In both plots, a drip irrigation installation was carried out, which also allowed the fertirrigation. The water was analyzed, highlighting the chlorine content $(288 \mathrm{mg}$ $\left.1^{-1}\right)$

Table 2. Plot surface, number of trees and spacing

\begin{tabular}{|c|c|c|c|c|}
\hline Plot & Area $\left.\mathbf{( m}^{\mathbf{2}}\right)$ & $\begin{array}{c}\text { Number of } \\
\text { trees }\end{array}$ & $\begin{array}{c}\text { Number of } \\
\text { border trees }\end{array}$ & Spacing \\
\hline (B) Biomass & 2048 & 264 & 74 & $3 \times 2 \mathrm{~m}$ \\
\hline (T) Timber & 3836 & 168 & 71 & $4 \times 4 \mathrm{~m}$ \\
\hline
\end{tabular}

Herbaceous vegetation was eliminated before the tillage. A full and crossed tillage has been carried out with a subsoil of up to $80 \mathrm{~cm}$.

Because of rabbits in the area protectors were installed with a $\varnothing 22 \mathrm{~cm}$ and a height of $33 \mathrm{~cm}$. After the resprouting in February 2013, the protectors were removed once the plants surpassed their height, to favor a uniform and vigorous regrowth.

Both plots were fertirrigated with a drip irrigation system, with 2 self-compensating drippers of $41 \mathrm{~h}^{-1}$ per tree. A Hunter X Core irrigation programmer was installed, connected to the existing irrigation system, to control the irrigation in both plots, assisted by a solar and rain sensor (Solar-Sync of Hunter), which regulates the irrigation time according to Humidity and radiation. The water comes from a well located at the ICMC. In addition, a venturi was installed for the fertilization.

\subsection{Stand Management}

The plantation was weeded with mechanical weed control machine. Later, in order not to damage the roots, herbaceous control was done by chemical treatments (Glyphosate and Oxyfluorfen), when necessary.

During the first year, pest damage was observed in very young plants due to Stagonomus bipunctatus, also known as rice bed bug or pudding. It was controlled by the combined use of Imidacloprid and 3\% Cipermetril accompanied by $1 \%$ Methylclorpirifos.

Along 2013 there were some trees of the B plot that were affected by Phytophthora citrophthora, which was isolated in the necrotic tissues. A phosphite treatment with Fosetyl aluminum was applied to soil [12], which proved very effective, since there were no more cases of attack by that fungus during 2014 or 2015 . After the first cut in February 2016, some sprouts were affected again, because of this treatment with Phosphites was repeated, resprouting all affected trees.

The irrigation dose was calculated based on evapotranspiration of the area and the needs of the plant. Irrigation dose was increased with the growth of the trees in the different plots, from 1 hour daily ( 6 days a week) the first year, to the current 2.5-3 hours (20 to 25 liters per tree), 4 days a week during the summer (around $6000 \mathrm{~m}^{3}$ ha $^{-1}$ year $^{-1}$ ).

In both plots $500 \mathrm{~kg} \mathrm{ha}^{-1}$ of a $15-10-15$ (N-P-K) fertilizer was applied from the beginning of June 2012 until June 2014. Humic and fulvic acids were added to improve the structure and soil exchange capacity. Since then (June 2014) a richer Nitrogen formulation of $15-5-5+3 \%$ Organic Matter has been applied.

Only the plot for the production of wood (M) was pruned to avoid bifurcations of the shaft and to produce a clean shaft of branches. In 2014 and 2015 shoots and branches on the shaft where eliminated of the up to a maximum of $2 / 3$ of the tree height.

\subsection{Measurements and Analysis}

The evolution of the total height was monitored, with measurements at the beginning and at the end of each growing period (only in plot T), and a biweekly or weekly follow-up of the measurements of the breast height diameter was carried out in both plots.

On the other hand, in February 2016, all the trees of the B plot were cut at the end of the first production cycle (3 years). After being cut down, all the trees were individually weighed, using a hook scale and a small crane. Later, they were chipped with a whole-tree chipper and samples from each clone were taken.

Moisture content was calculated according to ISO 18134-1:2015 (Solid biofuels. Determination of moisture content. Oven dry method. Part I: Total moisture). A slice of each stalk was removed after being cut. Slices were weighed individually (wet matter) and dried in a stove for 48 hours at $105{ }^{\circ} \mathrm{C}$ to obtain the dry weight. Ash content was determined with the chips sampled, according to ISO 18122:2015 (Solid biofuels. Determination of ash content). $\mathrm{C}, \mathrm{H}, \mathrm{N}, \mathrm{S}$ were measured using an elementary analyser Tru-Spec CHN Leco 4084, according to the standards ISO-16948 and ISO 16994 for biomass analysis. The $\mathrm{Cl}$ content in ash was determined with the titration method in accordance with ISO 16994. The chemical composition of ash in the Paulownia biomass was determined with an Inductively Coupled Plasma-Optical Emision Varian-715ES ISO 16968 (determination of trace elements: $\mathrm{Cu}, \mathrm{Pb}, \mathrm{Cr}, \mathrm{Ni}, \mathrm{Zn}, \mathrm{Mn}, \mathrm{Cd})$. Calorific value was determined according to ISO 18125 (Solid biofuel: Determination of calorific value).-Data analysis was performed using the statistical software $\mathrm{R}$ [12], and 
Agricolae package [13], to perform a comparison test of means of the studied parameters diameter and weight. With the measurements of diameters and weights corrected for moisture content, a parametric test of comparison of means was made. The accomplishment of this type of test requires the verification of three previous hypotheses: independence of the data, normality in the distributions and homoscedasticity. The first one was obtained with the design of the test in random blocks, the normality was verified through Kolmogorov-Smirnov test. Finally the homoscedasticity was verified through the Bartlett test to verify the homogeneity of variances for both variables. Subsequently a comparison of means test was performed: the Welch test for unequal variances and the Tukey's Honest Significant Difference test.

\section{Results}

Only the plot for biomass production has been evaluated, because the plot for timber production has not been cut yet, so its production has not been currently evaluated.

Measures are summarized in the following tables and figures (tables 3 and 4 , figures 2 and 3):

Table 3. Summary of measurements

\begin{tabular}{|c|c|c|c|c|c|c|}
\hline & Units & No. & Mean & S.D. & Min. & Max. \\
\hline Diameter & $\mathrm{mm}$ & 244 & 106.3 & 13.6 & 51.2 & 136.6 \\
\hline Wet weight & $\mathrm{g}$ & 244 & 40.2 & 11.3 & 7.2 & 70.8 \\
\hline Dry weight & $\mathrm{g}$ & 244 & 14.6 & 4.0 & 2.6 & 24.4 \\
\hline
\end{tabular}

$\mathrm{N}=$ Number S.D. Statistical Deviation

Table 4. Summary of diameters ( $\mathrm{mm})$ per clone

\begin{tabular}{|c|c|c|c|c|c|}
\hline & No. & Mean & S.D. & Min. & Max. \\
\hline $\mathbf{1 1 2}$ & 61 & 110.5 & 11.1 & 84.7 & 133.7 \\
\hline COT2 & 61 & 110.3 & 10.2 & 81.8 & 134.3 \\
\hline L1 & 61 & 110.6 & 10.2 & 91.0 & 136.6 \\
\hline X1 & 61 & 93.6 & 14.3 & 51.2 & 121.6 \\
\hline
\end{tabular}

Diameters

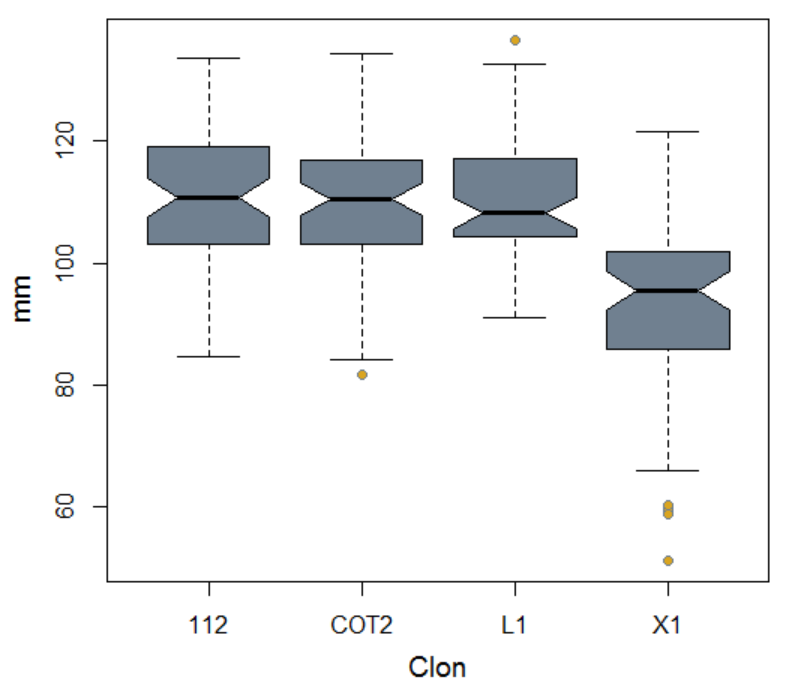

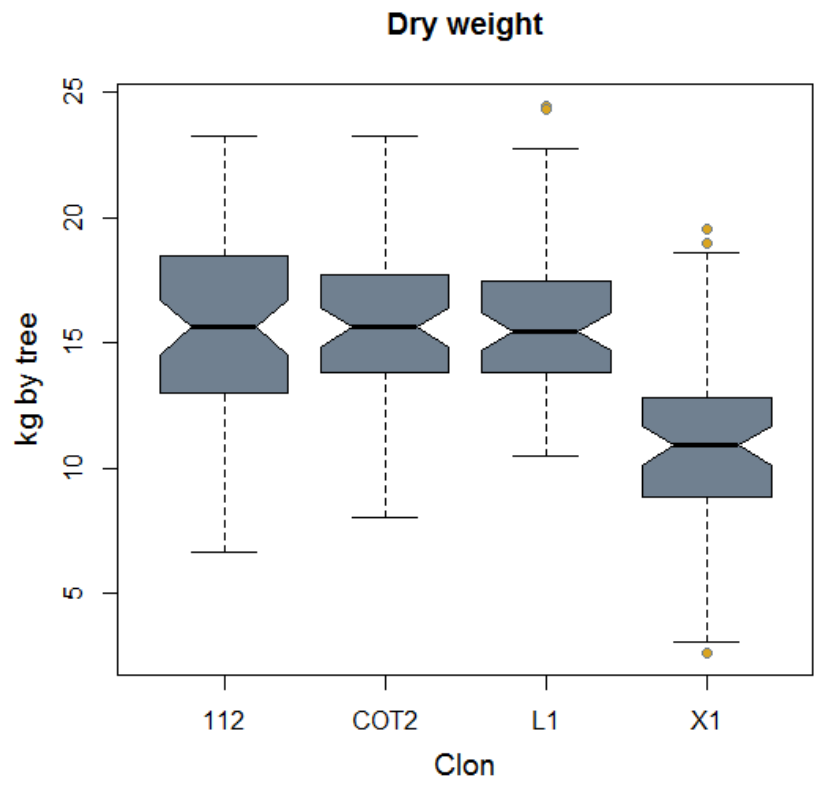

Figure 3. Dry weight $(\mathrm{kg})$ per clone

Table 5. Summary of dry weight $(\mathrm{Kg})$ per tree of each clone

\begin{tabular}{|c|c|c|c|c|c|}
\hline & N & Mean & S.D. & Min. & Max. \\
\hline $\mathbf{1 1 2}$ & 61 & 15.6 & 3.6 & 6.7 & 23.2 \\
\hline COT2 & 61 & 15.9 & 3.1 & 8.0 & 23.3 \\
\hline $\mathbf{L 1}$ & 61 & 16.1 & 3.5 & 10.5 & 24.4 \\
\hline $\mathbf{X 1}$ & 61 & 10.9 & 3.6 & 2.6 & 19.5 \\
\hline
\end{tabular}

In Figures 2 and 3 the distribution of the measurements of diameter and dry weight of each clone are shown, respectively. These distributions show a possible differentiated behavior of clone X1. In addition, the normality test of Kolmogorov-Smirnov verified the normality of both distributions.

The Bartlett test was employed to verify the homogeneity of variances for the diameter and dry weight variables. In the case of the diameters per clone the result of this test gives a p-value of 0.02071 , which means the homogeneity of variances is rejected with a probability of $95 \%$. This result entails to compare the means of the diameters using the Welch test, for unequal variances. However, in the dry weight variable the p-value is 0.5869 , so it is accepted the hypothesis of the homogeneity of variances which allows to perform a comparison analysis of Tukey's multiple means.

\subsection{Comparison of Means of Measurements of Diameters.}

The test is performed for each pair of clones. The results are reflected in the table 6

Figure 2. Diameters at breast height $(\mathrm{mm})$ per clone 
Table 6. Summary of diameters $(\mathrm{mm})$ per clone

\begin{tabular}{|c|c|c|}
\hline Comparative clones & $\mathbf{p}$-value & Signification level \\
\hline $112-$ COT2 & 0.8946 & \\
\hline $112-\mathrm{L} 1$ & 0.9871 & \\
\hline $112-\mathrm{X} 1$ & $3.952 \mathrm{e}-11$ & $* * *$ \\
\hline COT2 - L1 & 0.8766 & \\
\hline COT2 - X1 & $2.636 \mathrm{e}-11$ & $* * *$ \\
\hline L1 - X1 & $1.431 \mathrm{e}-11$ & $* * *$ \\
\hline
\end{tabular}

\subsection{Comparison Analysis of Means Measurements of Wood Weight at 0\% Moisture}

The analysis of the dry weight variance shows a high significance ( $\mathrm{p}$-value $\approx 0$ ), so all clones have not the same behavior in terms of their dry weight production. This variable is submitted to the HSD test, to compare unpaired means.

On the other hand, it has been verified that membership of a given block does not act as a differentiating factor in the production of biomass.

Table 7. HSD test result

\begin{tabular}{|c|c|c|}
\hline Clone & Mean & Group \\
\hline L1 & 16.07 & a \\
\hline COT2 & 15.90 & a \\
\hline 112 & 15.62 & a \\
\hline X1 & 10.93 & b \\
\hline
\end{tabular}

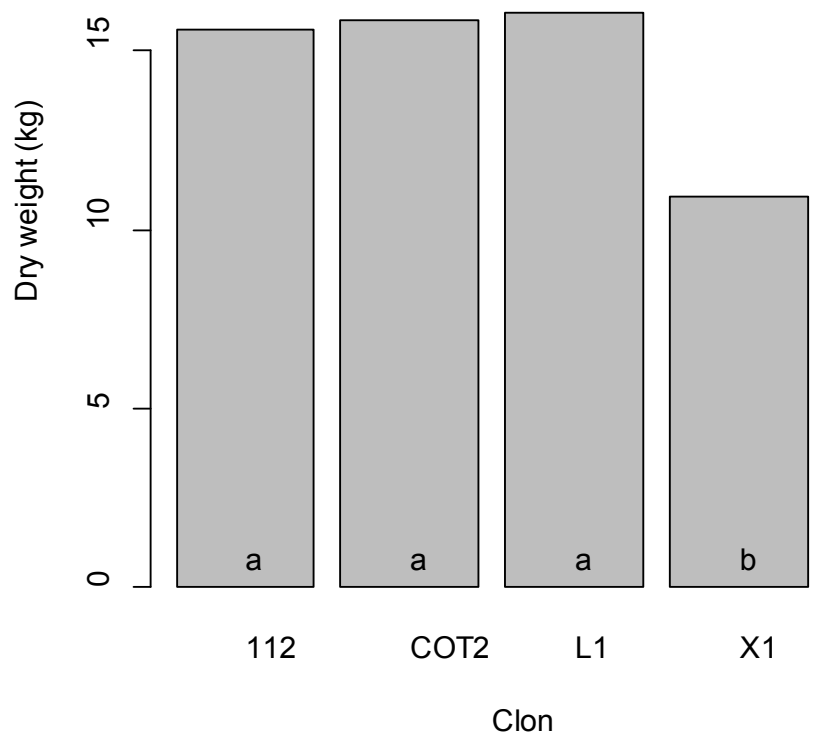

Figure 4. Groupated dry weight means $(\mathrm{kg})$

The results obtained conclude that clone X1 has a significantly lower dry biomass production than the other three tested clones.

\subsection{Analysis of the Biomass Composition for Different Clones after Chips}

Splinter samples were taken from the different clones attempting to represent all parts of the tree, obtaining mean values. They are showed in Tables 8 and 9 .

Table 8. Elemental analysis and calorific values

\begin{tabular}{|c|c|c|c|c|c|c|c|c|c|c|}
\hline \multirow[b]{2}{*}{ CLONE } & \multirow[b]{2}{*}{$\%$ HUMIDITY ${ }^{1}$} & \multirow[b]{2}{*}{$\% \mathrm{ASH}^{2}$} & \multirow[b]{2}{*}{$\% \mathrm{O}^{4}$} & \multirow[b]{2}{*}{$\% \mathrm{Cl}^{3}$} & \multicolumn{4}{|c|}{ ELEMENTAL ANALYSIS ${ }^{4}$} & \multicolumn{2}{|c|}{ CALORIFIC VALUE ${ }^{5}$} \\
\hline & & & & & $\% \mathrm{C}$ & $\% \mathrm{~N}$ & $\% \mathrm{H}$ & $\% \mathrm{~S}^{3}$ & $\begin{array}{c}\mathrm{LCV} \\
\text { (Kcal/kg) }\end{array}$ & $\begin{array}{c}\mathrm{HCV} \\
\text { (Kcal/kg) }\end{array}$ \\
\hline $\mathbf{X} 1$ & 64.85 & 1.95 & 44.05 & 0.07 & 47.31 & 0.41 & 6.04 & 0.01 & 4414 & 4731 \\
\hline COT 2 & 62.79 & 1.96 & 42.51 & 0.12 & 51.56 & 0.45 & 5.60 & 0.02 & 4425 & 4718 \\
\hline 112 & 63.02 & 1.51 & 46.07 & 0.14 & 46.01 & 0.21 & 5.89 & 0.00 & 4341 & 4650 \\
\hline L1 & 63.55 & 1.85 & 45.66 & 0.08 & 45.89 & 0.27 & 6.04 & 0.00 & 4437 & 4753 \\
\hline
\end{tabular}

1: UNE-EN ISO 18134-1, 2: UNE-EN ISO 18122, 3: UNE-EN ISO 16994, 4: UNE-EN ISO 16948, 5: UNE-EN ISO 18125.

Table 9. Heavy metal analysis

\begin{tabular}{|c|c|c|c|c|c|c|c|}
\hline & \multicolumn{7}{|c|}{ ANALYSIS ICP-OES } \\
\hline CLONE & $\mathbf{C u}(\mathbf{p p m})$ & $\mathbf{P b}(\mathbf{p p m})$ & $\mathbf{C r}(\mathbf{p p m})$ & $\mathbf{N i}(\mathbf{p p m})$ & $\mathbf{Z n}(\mathbf{p p m})$ & Mn (ppm) & Cd (ppm) \\
\hline $\mathbf{X 1}$ & 3.65 & 0 & 0.48 & 0.6 & 9.34 & 5.03 & 0.25 \\
\hline COT 2 & 6.01 & 0 & 0.54 & 0.8 & 8.98 & 8.03 & 0.10 \\
\hline $\mathbf{1 1 2}$ & 4.67 & 0 & 0.41 & 0.81 & 8.80 & 4.27 & 0.22 \\
\hline $\mathbf{L 1}$ & 8.67 & 0 & 0.63 & 1.22 & 10.88 & 5.03 & 0.22 \\
\hline
\end{tabular}

6: UNE-EN ISO 16968 


\section{Discussion}

The membership of the given block in the plot B does not determine the biomass production. Therefore, the dry biomass production of $\mathrm{X} 1$ clone is significantly lower than the other three tested clones according the results obtained. Furthermore, $\mathrm{X} 1$ is the only clone of the Paulownia fortunei species, and the other studied clones are of the Paulownia elongata $x$ fortunei species.

Significant differences are not found among biomass production of clones 112 , COT2 or L1.

The total production of plot B was $24280.1 \mathrm{~kg} \mathrm{~d} . \mathrm{m} \mathrm{ha}^{-1}$. 8093.4 Kg d.m. ha ${ }^{-1}$ year $^{-1}$ for the total of the plot with the sum of the 4 clones. According to Del Cerro [14], clone 112 was studied and its production was $6079.13 \mathrm{~kg} \mathrm{~d} . \mathrm{m} \mathrm{ha}^{-1}$ (in 17 months) or, what is the same, $4291.15 \mathrm{~kg} \mathrm{~d} . \mathrm{m} \mathrm{ha}^{-1}$ year $^{-1}$, under planting, irrigation and subscribes similar conditions. In another study, Jimenez Bocanegra et al. [15], obtained between 1.7-14 $\mathrm{Tn}^{\mathrm{d}} \mathrm{m} \mathrm{ha} \mathrm{m}^{-1}$ in 2 years $(0.85-7 \mathrm{Tn}$ d.m $\mathrm{ha}^{-1}$ year ${ }^{-1}$.) with clone COT2 with similar experimental conditions. The difference in the productions may be due to edaphoclimatic conditions and the different coppicing cycle.

The results obtained from the tests carried out in plot B, from the determinations of moisture, ash, oxygen, chlorine, elemental analysis $(\mathrm{C}, \mathrm{H}, \mathrm{N}$ and $\mathrm{S})$, calorific value and minority elements, in the Paulownia chips, appear in tables 8 and 9. All values obtained satisfy the solid biofuels regulation for wood chips class B1 [16], except chlorine. The water used in irrigation comes from a well with a high content of chlorine $\left(153 \mathrm{mg} \mathrm{l}^{-1}\right)$ and other elements, exceeding the levels of drinking water in Merida $(46 \mathrm{mg} \mathrm{Cl}$ $\left.1^{-1}\right)$. However, another sample of Paulownia chips from another CICYTEX experimental plot, at La Orden Experimental Farm in Guadajira (Badajoz), was irrigated with water from the channel used by farmers on their plots and it has got a lower value Chlorine content $(0.01 \%)$ than the previous sample, meeting the standard of solid biofuels (maximum limit $0.05 \%$ ). Kasamaky [17] obtained similar values in the characterization of the Paulownia biomass. Values of HCV are located in the range of 4200 and 4400 Kcal $\mathrm{kg}^{-1}$ depending on the analyzed clone, while the ash percentage is around $2 \%$. The analysis carried out by the Renewable Energy Research Institute "IER" [18] also presented similar values.

\section{Conclusions}

The Paulownia plantations are viable in the area of "Las Vegas Bajas del Guadiana". These conditions are extrapolable to areas of Extremadura Region (Southwestern SPAIN), as long as the conditions of the soils are well aerated, not clayey, without flooding for long time and good availability of irrigation in the early years. Subsequently, although the irrigation may not be necessary, they advantage the growth and development of this species.
Chlorine is easily assimilable by the clones in study, remaining in the wood after the cut, so that can be a conditioning in certain areas with water rich in this element.

Considering the results, the similar behavior of clones L1, COT2 and 112 has been observed in their growth in diameter, as well as in biomass yield. These clones are significantly higher than clone $\mathrm{X} 1$, it means that these three clones are better adapted to the studied area. Therefore, the choice of any of these clones cannot be made on the basis of their biomass production or growth, under the conditions of cultivation and station quality in which this test was performed.

The total production of the plot for biomass production was $24280.1 \mathrm{~kg} \mathrm{~m} . \mathrm{s}$. ha ${ }^{-1}$ with a three years coppicing cycle, that is $8093.4 \mathrm{Kg} \mathrm{m} . \mathrm{s}$. ha ${ }^{-1}$ year $^{-1}$ for the total plot.

On the other hand, from the sanitary point of view, these Paulownia clones show a good behavior against pests, although they are more sensitive in the first stages of growth. It is clear the sensitivity to the attack of some pathogenic fungus of agricultural origin like Phytophthora citrophthora, for which the application of phosphites to soil could be an effective treatment.

\section{Acknowledgements}

I am grateful for CICYTEX`s partners help and support, especially those located at I.C.M.C. for their patience and dedication in fieldwork and measurement, especially Adrián J. Montero, alma mater of this project.

\section{REFERENCES}

[1] J.L. Gutierrez, R. Ocaña. Manual para el cultivo de Paulownia elongata. Universidad Autónoma del Estado de México. México. 2009.

[2] Z.H. Zhu, C.J. Chao, X.Y. Lu,Y.G. Xiong. Paulownia in China: cultivation and utilization. Asian Network for Biological Sciences and International Development Research Centre, Otawa, Canada. 1986.

[3] A. Ashori, A. Nourbakhsh. Studies on Iranian cultivated Paulownia a potential source of fibrous raw material for paper industry. European Journal of Wood and Wood Products 67 (3), 323-327. 2009.

[4] M. Beel, S. Davis, J. Murphy, P. Piper. Product potential of Paulownia timber. Australian Forestry. 68 (1), 3-8. 2005.

[5] S.M.M. Tari, S. Habibzade, H.R.Taghiyari. Effects of Drying Schedules on Physical and Mechanical Properties in Paulownia Wood DRYING TECHNOLOGY Vol. 33 No. 15-16, 1981-1990.Taylor and Francis Group LLC. 2015.

[6] PB1465 Tree Crops for Marginal Farmland - Paulownia," The University of Tennessee Agricultural Extension Service, 05-0012PB1465-1M-1/05(Rev) E12-4915-00-005-05. 
Online available http://trace.tennessee.edu/utk agexfores/3.

[7] B.A. Bergman. Five years of Paulownia field trials in North Carolina; New Forest, Vol. 25, 185-199, 2003.

[8] D.H. Graves, J.W. Stringer. Paulownia: A guide to establishment and cultivation. University of Kentucky. Cooperative Extension Service, FOR-39, 1989.

[9] M.E. Lucas, E. Martínez, F.A. García, F.R. López, M. Andrés, D. Pérez, A. del Cerro. El cultivo de Paulonia (Paulownia elongata $\mathrm{x}$ fortunei) para la obtención de madera y biomasa en Castilla-La Mancha: Primeros resultados. COITF. Revista foresta $n^{\circ} 47-48,106-110,2011$.

[10] L. van de Hoef. Paulownia. Agriculture Notes, Ag: 1-3, 2003.

[11] J.J. Tuset, I. Lapeña, J.M. García-Mina; Efecto fungitóxico del ácido fosforoso en naranjo dulce a la infección con zoosporas de Phytophthora citrophthora. MAGRAMA, Bol. San. Veg. Plagas, n²9, 413-420. Spain, 2003.

[12] R Core Team (2016). R: A language and environment for statistical computing. R Foundation for Statistical Computing, Vienna, Austria. Online available from: https://www.R-project.org/.
[13] F. de Mendiburu (2015). Agricolae: Statistical Procedures for Agricultural Research. R package version 1.2-3. Online available from: https://CRAN.R-project.org/package=agricolae.

[14] A. del Cerro; Forestación de zonas semiáridas de Castilla-La Mancha con Paulownia spp. ETSIAM de Albacete, Departamento de Ciencia y Tecnología Agroforestal y Genética. Albacete, 2009.

[15] V.H. Duran Zuazo, J.A. Jimenez Bocanegra, F. Perea Torres, C.R. Rodríguez Pleguezuelo, J.R. Francia Martinez. Biomass Yield Potencial of Paulownia Trees in a Semi-Arid Mediterranean Environment (S. Spain) International Journal of Renewable Energy Research. Vol.3, No4, 2013.

[16] UNE-EN ISO: 17225-4, 16994, 16968, 18122, 16948, 18134-1, 14918. Biocombustibles sólidos.

[17] P. Kasamaky. La Paulownia como base de los cultivos energéticos, Online available from:

http://www.icoitma.com/imagenes/imagenes-noticias/id258 A.pdf.

[18] IER (Instituto de Investigación en Energías Renovables). Online available from: http://paulownia1 12.com/wp-content/uploads/2012/12/INF ORME-DE-RESULTADOS-MS344-ANALISIS-BIOMAS A-CLON-IN-VITRO-112r.pdf, 2012. 